ECONOMICS

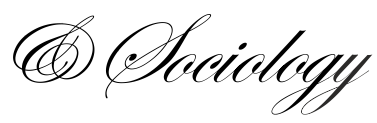

Wadim Strielkowski, Cambridge Judge Business School, University of Cambridge, Cambridge, United Kingdom, E-mail: w.strielkowski@jbs.cam.ac.uk.

\author{
Yuri Tumanyan, \\ Southern Federal University, \\ Rostov-on-Don, Russian \\ Federation, \\ E-mail:yrtumanyan@sfedu.ru \\ Svetlana Kalyugina, \\ North-Caucasus Federal University \\ Stavropol, Russian Federation \\ E-mails:s.kalyugina@gmail.com
}

Received: March, 2016

1st Revision: May, 2016

Accepted: June, 2016

DOI: $10.14254 / 2071-$

789X.2016/9-2/20

\section{LABOUR MARKET INCLUSION OF INTERNATIONAL PROTECTION APPLICANTS AND BENEFICIARIES}

\begin{abstract}
This paper discusses the labour market inclusion of international protection applicants and beneficiaries with a special focus on the Czech Republic. The issue of letting the asylum seekers and refuges to enter the labour markets of the Members States freely and without obstacles constitutes a hot-debated topic in the EU and differs from country to country. One can say that this topic was taken out of context and exploited during the recent Brexit campaign that resulted in an unexpected "leave" vote that shocked the United Kingdom. The migration card was played mainly for political reasons. However, most people forget that almost 3 million people born in the UK currently reside in other EU countries (which is about the same amount as the number of people born in other EU countries living in the UK.

The Czech Republic is a different story altogether. It represents a typical immigration country with all its characteristic features, yet the nature of the incoming migration. The analysis of the provisions and regimes in the Czech Republic shows that the country (similar to most of the EU Member States) is not very attractive for asylum seekers in general but those international protection applicants who chose to go there, do this on purpose as a part of their carefully planned migration strategy. The structure and the mix of asylum seekers in the Czech Republic seem to prove this postulate.
\end{abstract}

JEL Classification: J40, J61, F15
Keywords: international migration, labour market, asylum seekers, refuges, Czech Republic.

\title{
Introduction
}

Labour market inclusion of international protection applicants and beneficiaries represents an important issue of migration and integration policies of various EU Member States.

Strielkowski (2012) and Miłaszewicz et al. (2015) show that immigrants often choose host countries according to the ability to absorb an additional labour supply that they constitute. As a result, certain EU Member States experience the influx of the large amount of immigrants that might potentially cause disturbances on their labour markets. The stakeholders and migration policy-makers, as well as labour associations, trade unions and 
members of general society confront the constant dilemma of allowing migrants to enter their respective countries and facing consequences that might follow including social unrests, unease, the rise of populism and xenophobia. With regard to the above, there is no wonder that the recent Brexit campaign recently waging in the United Kingdom and shaking up the political and economic scenes prior to the referendum held on the $23^{\text {rd }}$ of June 2016 was largely drawing from the fears of migration and "flooding" the UK labour market (Vasilopoulou, 2016). In fact, the "Brexiteers" used migration as their main card a week or two before the day of the referendum trying to tip the vote to their side. It is ironic that possible consequences of Brexit might turn this debate around. According to the Office of National Statistics (2011), in 2011 alone, 2.68 million people born in other EU countries resided in the United Kingdom. This number reached 3.03 million by 2014 (Office of National Statistics, 2014). In the same time, there might be from 1.2 to almost 3 million people born in the UK or having the UK passport who live and work in other EU countries (Parliament, 2016). What might follow would be naturalization of migrants on either sides or the massive exodus if all other measures and solutions fail to resolve the situation.

A common concern about the phenomenon of international migration that might shape the policies and the public attitudes is the common perception that migrants come into a country without any contribution to society and that they might only take the advantage of the conditions local labour markets and welfare states offer.

In order to measure levels of integration and labour market inclusion, "Migrant Integration Policy Index" (MIPEX) is often employed (Niessen et al., 2010). The MIPEX is a tool that allows measuring and comparing diverse levels of integration with regard to different migration policy areas such as labour market mobility, education and access to long term residence, among other things. With the data contained in this index, the impact of integration in the immigration surplus might be explained and then used to generate advices that might improve integration and thus enhance economic benefits for local economy.

The rest of this paper is structured as follows: Section 1 describes the situation with the international protection in the Czech Republic. Section 2 discusses the Czech migration policy and provisions with regard to the international protection applicants and beneficiaries. Section 3 analyses the issues of "immigration surplus" and MIPEX for the particular case of the Czech Republic. Finally, Section 4 summarizes the main findings and provides brief conclusions and policy implications.

\section{International protection regimes in the Czech Republic}

The Czech Republic has never been a very popular country for international migrants (except for the Ukrainians, Vietnamese of the citizens of the neighbouring Poland and Slovakia). Moreover, the number of applications for international protection in the Czech Republic has never been high in comparison with the other EU countries.

In 2015, foreign nationals filed 1525 applications for international protection in the Czech Republic. The asylum was granted to 71 people and 399 people were put under the supplementary procedure (permission to stay in the country for a period from 1 to 3 years).

Chart 1 shows the total number of applications for international protection between 1993 and 2015. It becomes apparent that the average annual number of applications is around 2000 with a steep rise in 1999-2004 which was mainly due to the Slovak Roma "holiday" asylum migration. In those days, (predominantly) Slovak Roma migrated to the Czech Republic and applied for asylum in order to spend several months in detention centres with all expenses paid. The Roma regarded that situation as a routine escape from the poverty and debts in their native areas of habitat (see Strielkowski, 2012). 


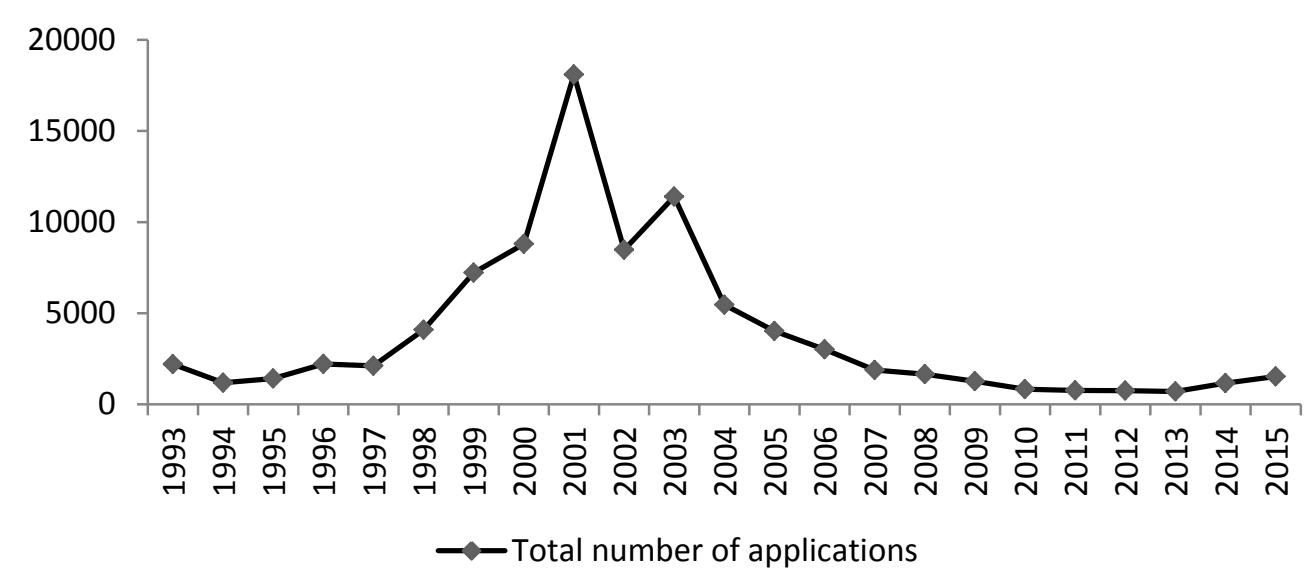

Chart 1. Total number of applications for international protection (1993-2015) Source: CSO (2015) and Ministry of the Interior (2015).

Chart 2 shows the repeated applications and the new applications to the total number of applications.

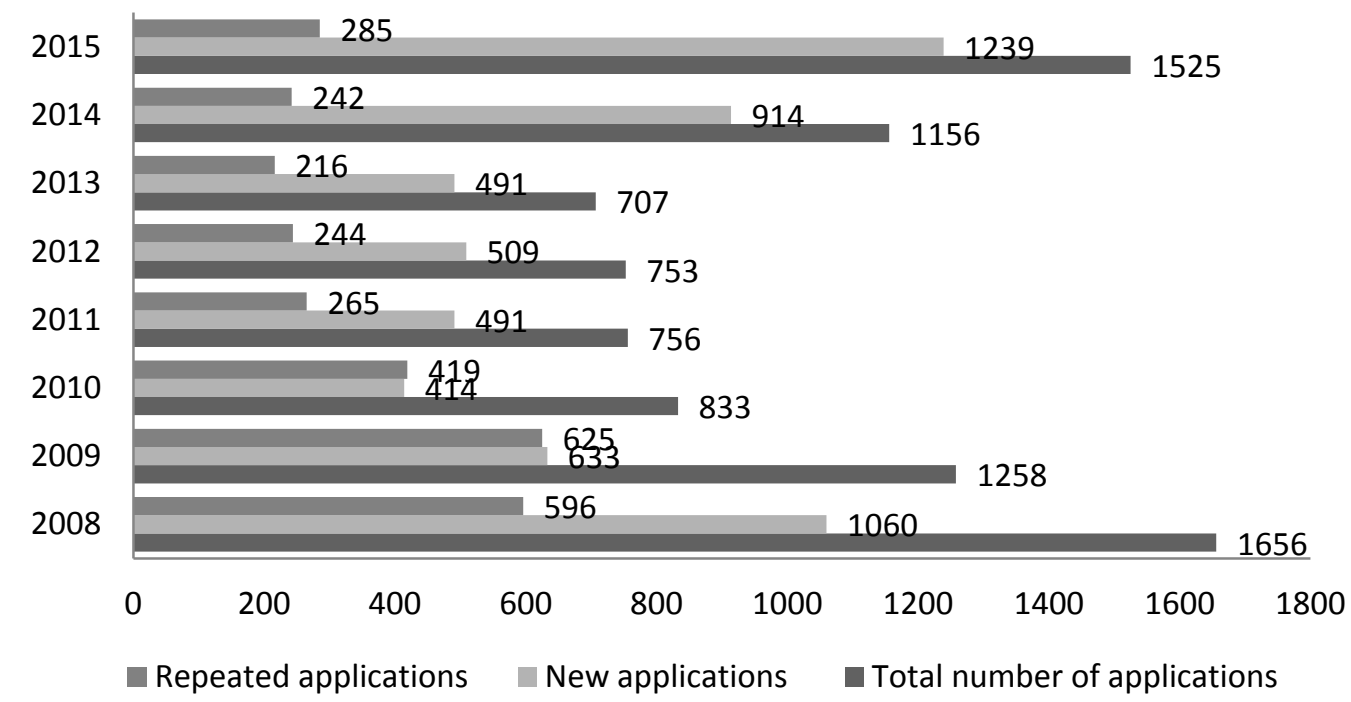

Chart 2. Repeated \& new applications for international protection (2008-2015) Source: Ministry of the Interior (2015).

Chart 3 lists the top 10 citizenships of applicants: the first place is occupied by Ukraine followed by Syria, Cuba, and Vietnam. It is peculiar that the list is led by the citizens of the states with which former socialist Czechoslovakia had good relations as well as cultural and economic ties in the past. 


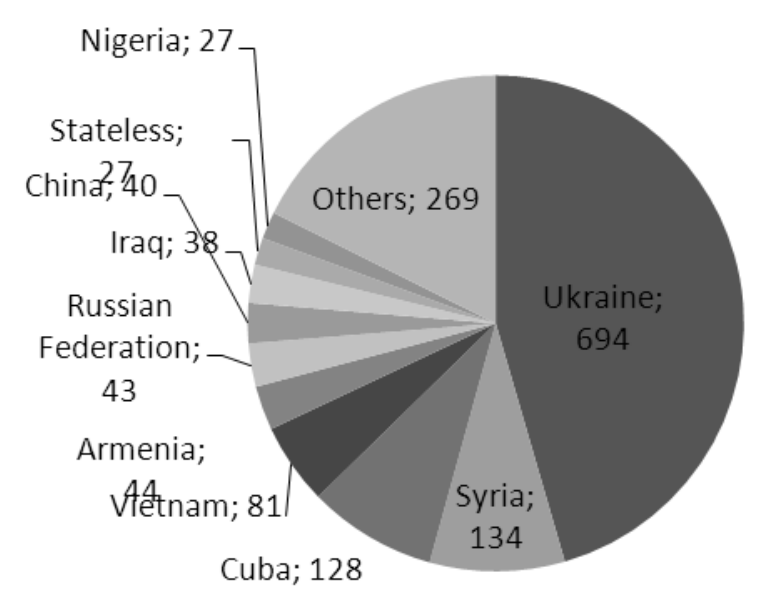

Chart 3. Top 10 citizenships of applicants for international protection in 2015 Source: Ministry of the Interior (2015).

Chart 4 lists the total number of persons with valid international protection residing in the Czech Republic as per December $31^{\text {st }}$ 2014. This time, Belarusian, Russian, and Ukrainian citizens $(375,333$, and 292 persons) are on the top of the list. This arrangement is mainly due to the high number of applications from the nationals of these countries submitted at the end of the 1990s and the beginning of the 2000s, when the political turmoil and tensions between the citizen groups and the regimes in the countries in question led to the massive outward migration to the West (Strielkowski and Sanderson, 2013; Strielkowski and Weyskrabova, 2014; or Ambrosetti et al., 2014).

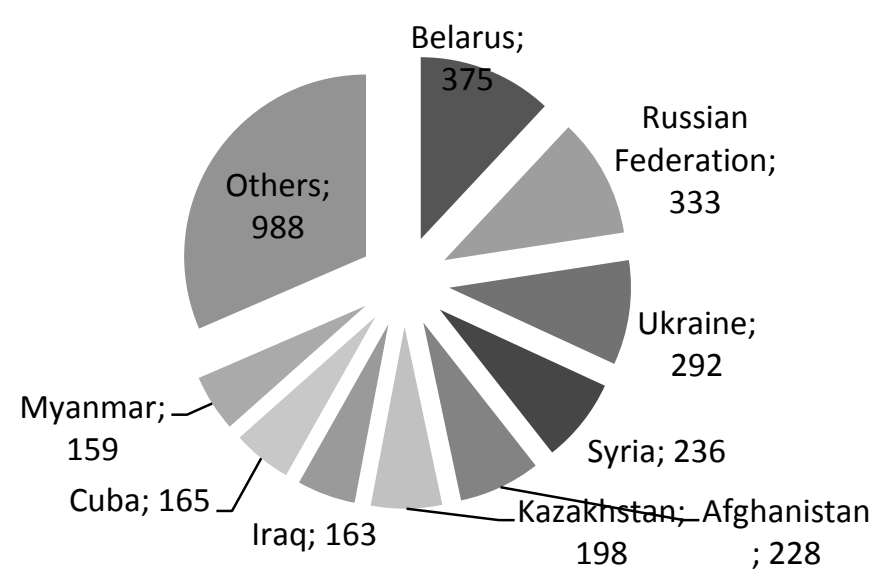

Chart 4. Persons with valid international protection

Source: Ministry of the Interior (2015).

Overall, the number of granted asylums in the Czech Republic is very low - about 1$2 \%$ of all applications are approved preceded by 2-3 years of asylum procedure and a thorough investigation. However, the problem is that during this investigation the foreign national are placed to the asylum facilities that are often located in remote areas with little contact to the local culture and environment and a very limited possibility to engage in a paid employment. The majority of the applicants for international protection in the Czech Republic survive from the social benefits. 
The motivation of asylum seekers and refugees in the Czech Republic might be very different from those heading towards other EU states. Migrants from the Middle East and Africa do not feel very welcomed in the Czech Republic and are rather interested in neighbouring Germany. Another interesting feature is the increase in the number of asylum seekers from Ukraine in the recent years - perhaps some interesting parallels and comparisons can be drawn to map the profile and motivation of these refugees and their progress in labour market integration in the Czech Republic where Ukrainians always constituted the majority of third-country nationals, and the other EU Member States (Mishchuk \& Grishnova, 2015).

\section{Migration policies and labour market regulations}

In the Czech Republic, migration and integration of foreigners falls under the agenda of the Ministry of Interior of the Czech Republic. The Ministry of Labour and Social Affairs of the Czech Republic is responsible for the labour market policies, including those related to the employment of the foreigners, persons applying under international protection and refuges. The requests for obtaining short and long term visas are submitted through the embassies, therefore it partly falls under the jurisdiction of the Ministry of Foreign Affairs of the Czech Republic.

The main principle of the Czech migration policy towards the citizens of the third countries is the possibility of obtaining the long-term residence provided that the applicant meets the conditions based on the purpose of her or his stay (paid employment, study, selfemployment, and/or marriage). The number of applicants is done via the online registration system called "Visapoint" which determines how many applications for residence permits and visas can be accepted by the individual embassies. Thence, the Czech migration policy is not based on the formal quotas or a point system but represents an informal system with the regulated number of visa applications. A combination of the two principles (the need to fulfil the requirement for a purpose of stay, for example, finding a job or getting accepted to the accredited higher education institution, and the quota system) leads to the fact that some potential migrants who meet all the requirements for the long-term visas do not get an opportunity to apply at all.

After 1993 the Czech Republic quickly became immigration as well as the transit country. Its migration policy in the late 1990s and early 2000s was relatively liberal until the number of foreigners in the country started to increase which resulted in raising awareness by the media and the general public. In spite of all the efforts, no comprehensive national migration strategy was formed and practices and regulations towards the foreigners were tightening. It was the synchronisation with the EU regulations in the context of accession negotiations with the European Union and harmonization Czech legislation with the EU laws that triggered off the new wave of taking the migration policy seriously. From 2000 to 2008, the number of foreigners in the Czech Republic doubled and reached 450.000 persons. In spite of this, the structural assistance for migrants, as well as their integration into society remained very poor. The legislation on migration of foreigners was regulated by the 1999 Act no. 326/1999 Coll. "On the residence of foreigners in the Czech Republic" and the Act no. 325/1999 Coll., "On asylum”.

Another important change came with the introduction of Law no. 314/2015 Coll., which came into force from 18 December 2015. The Law introduced a new time limit for access to the labour market set for six months (similar to the case of the Host country), in accordance with the EU legislation. This period often coincides with the length of procedures needed to obtain refugee status.

In 2011, about 300000 foreigners in the Czech Republic (about 70\% of all foreigners in the Czech Republic) were officially employed (the rate of employment for the Czech 
citizens in the same year was about 55\%). Around one third of them were self-employed (acted as sole traders) and the rest were employees. Men represented two-thirds of all foreigners.

Similar to the situation other EU Member States, employers, public officials, and relevant stakeholders in the Czech Republic do not have sufficient information about the asylum seekers and refugees' legal status, neither there exist clear statistics about how well the refugees are placed on the Czech labour market (after being granted international protection, they become "locals" in the labour statistics). Moreover, the current refugee crisis acts as a demotivating element, making the employment of "migrants" a very sensitive topic among the Czech potential employers.

Moreover, there are two interesting cases from the Czech Republic that can be mentioned within this context: integration of migrants that occurs at the regional and local level, with municipalities and counties being the key players of the integration policy. The Czech Ministry of Interior initiated the establishment of regional centres for promote the integration of third country nationals. The centres were financed from the projects partly funded by the European Fund for the Integration of non-EU migrants (EIF) in 2009-2015, and the Asylum, Migration and Integration Fund (AMIF) from 2015 hereinafter. Another interesting aspect is the massive engagement of non-profit organizations and NGOs with the issue of international migration, including the labour market integration of international protection applicants into the Czech Republic. There are currently 38 such organizations, including a broad spectrum of entities, including such famous ones as People in Need, or Multicultural Centre Prague. These NGO are very successful in preparing interesting and timely projects and securing EU funding.

\section{MIPEX and immigration in the Czech Republic}

In 2011, about 300 thousand foreigners in the Czech Republic (about 70\% of all foreigners in the Czech Republic) were officially employed (the rate of employment for the Czech citizens in the same year was about 55\%). About $1 / 3$ of them were self-employed (acted as sole traders) with men representing $2 / 3$ of all foreigners and the rest were employees.

The question arises: what is the economic impact on migration on the host country's labour market expressed in monetary terms? Scientific community as well as the general public are keen on seeing the actual results of incoming migrations, the real outcomes of migration policies and would like to know whether the theory can be applied to practice. The answer to this question can be found in the so-called "immigration surplus model" which is currently one of the most credible and verifiable ways how to measure the impacts of immigration on the economy of the receiving country and it has been widely applied in the research literature (see e.g. Bilan and Strielkowski, 2016; Bilan, 2014a, b). It can be shown that the immigration surplus (the benefits from incoming labour migration to the Czech Republic) constituted about $0.04 \%$ of GDP (around 73 million EUR for the 160 billion EUR Czech economy) in 2009 (see Stojanov et al., 2011). This demonstrates that migration has a net positive effect on the economy of the receiving country and the overall welfare effect is almost always likely to be positive.

Successful integration of third-country nationals might help to structure a legal environment where these groups might co-exist with the rest of the population and contribute to the well-being and social welfare. Such factors as free access to employment, education, public security might encourage those migrants to interact with the local societies and thus contribute to the overall development (Lodewyckx et al., 2010; Androniceanu, 2015). 
The MIPEX index mentioned in the Introduction of this paper is often used as measure of integration policies for a sample of more than thirty countries. It is also used as a reference point for evaluating, comparing and improving the overall situation of immigrants in the respective host countries.

MIPEX index contains 148 policy indicators that describe the conditions that a legal immigrant has to fulfil in order to participate economically and politically in the life of the respective host society. Using this methodology, the index allows us to establish whether the third-country nationals are treated in the same way as the natives.

In general, MIPEX index analyses seven policy areas: labour market mobility, family reunion, education, political participation, long-term residence, access to nationality and antidiscrimination. These seven policy areas are divided into 35 policy indicators. Every policy indicator consists in a question related to a specific area that constitutes an integral part of MIPEX. The benchmark for every policy indicator is the highest EU or international standard that guarantees the equal rights, responsibilities, and opportunities for all the residents in a given country (nationals, foreign-born or third-country nationals). Therefore, the following scheme is applied:

- 3 points - The policy area scores the maximum because it meets the highest standards for equal treatments or all residents and non-residents.

- 2 points - The policy area is somewhere half-way between the highest standards and the lowest standards.

- 1 point - The policy area gains the minimum because it is far from the highest standards. If a country does not have policies that a specific policy indicator requires, the grade of 1 is given as a default.

Furthermore, the scores are averaged within each of the seven policy areas in order to be transformed into the four dimensional score that examines the same aspect of the policy. These four dimensional scores are then averaged together in order to compute the respective policy area scores for each of the seven policy areas in a given country. Finally, the results are averaged together in order to compute the overall scores for each respective country. In order to develop a ranking table of countries, the initial 1-3 scale is transformed into a 0-100 scale where $100 \%$ represents the top score.

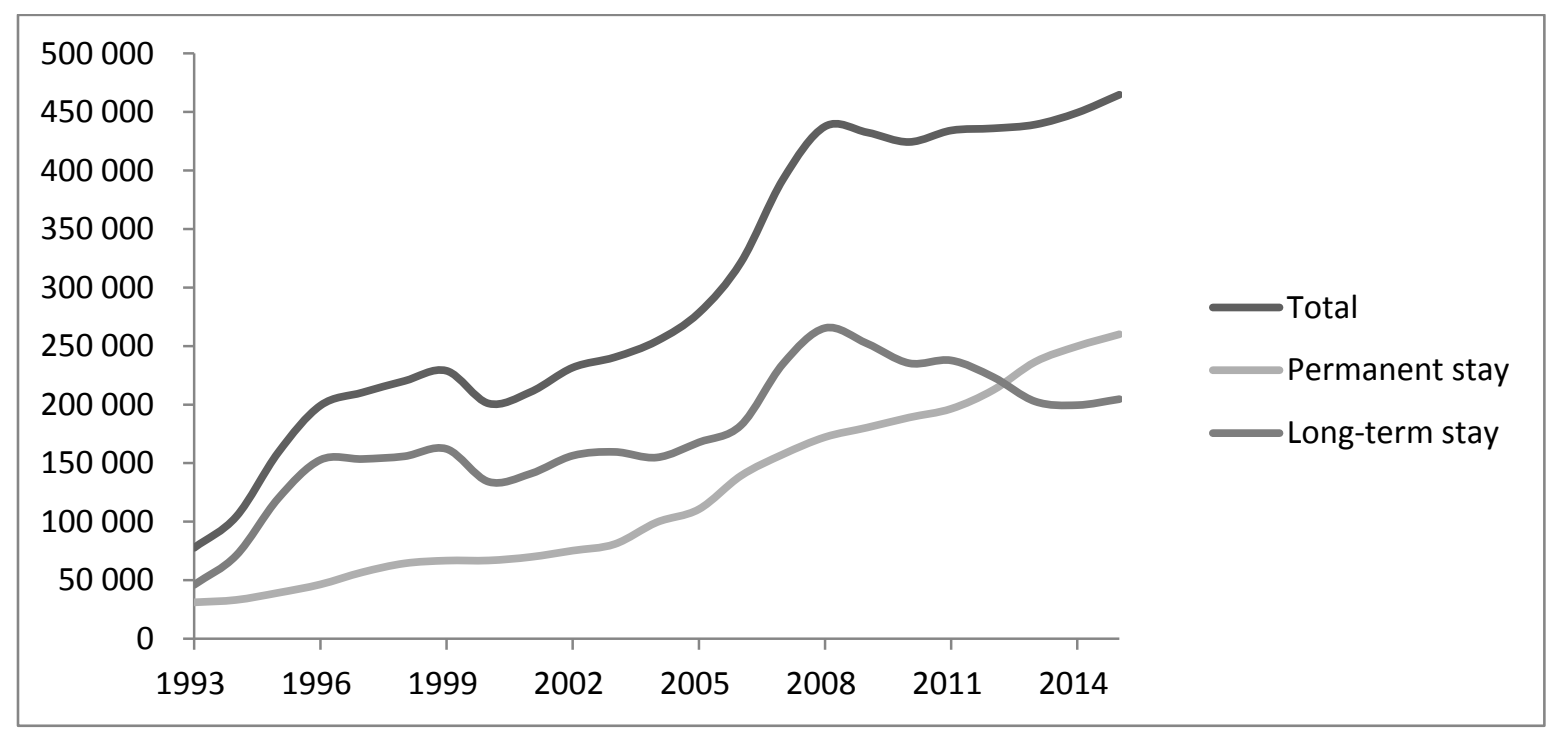

Chart 5. Migrants in the Czech Republic by type of residence (1993-2015)

Source: CSO (2016). 
According to the MIPEX methodology, in 2014 (the last year the index is calculated for) the Czech Republic had an overall score of 45 which falls under the category of "Halfway favourable" (41-59 points) (MIPEX, 2016).

With a total population of 10.5 million people, the Czech Republic had just short of half a million migrants residing in the country in 2015 (464.670 migrants). Chart 5 shows the dynamics of migration to the Czech Republic. One can see that the numbers are quite modest and it becomes clear that the Czech Republic can hardly be called a country with a high immigration.

The Czech Republic cannot be regarded as the good example of market integration of international protection applicants and refuges. The country is hardly attractive for asylum seekers and refuges and if these people end up in the country, this is happening due to the fact they mostly use it as a bridge (or an international springboard) for the neighbouring Germany.

The empirical model used in this paper shows the relation between the immigration surplus and the migrant policy indicators. The model can be presented in the following way:

$$
I S_{c, t}=\alpha \tau_{c, t}+Z_{j}\left\{\beta_{j} A L M_{c, t}+\beta_{j} S L R_{c, t}+\beta_{j} A N_{c, t}\right\}+\sigma \varepsilon_{c, t}
$$

where:

IS - is an immigration surplus;

ALS - is an access to labour market;

SLR - is a security of long-term residence;

$\mathrm{AN}-$ is an access to obtaining the nationality (citizenship); $\sigma-$ is the representation of the residuals.

The results of the model's estimations are shown in Table 1 that follows:

Table 1. Empirical model of immigration surplus and migrant policy indicators (2007-2012)

\begin{tabular}{|c|c|c|c|c|}
\hline Residuals & & & & \\
\hline Min & $1 \mathrm{Q}$ & Median & $3 Q$ & Max \\
\hline-0.075858 & -0.001048 & 0.000802 & 0.003062 & 0.029817 \\
\hline \multicolumn{5}{|l|}{ Coefficients } \\
\hline & Estimate & Standard error & $\mathrm{T}$ - value & $\operatorname{Pr}(>|t|)$ \\
\hline (Intercept) & $-5.39 \mathrm{e}-03$ & $2.31 \mathrm{e}-03$ & -2.328 & $0.020962 *$ \\
\hline SLR & $1.08 \mathrm{e}-04$ & $4.12 \mathrm{e}-05$ & 2.613 & $0.009696^{* *}$ \\
\hline ALM & $6.01 \mathrm{e}-05$ & $2.45 \mathrm{e}-05$ & 2.450 & $0.015190^{*}$ \\
\hline $\mathrm{AN}$ & $-1.43 e-04$ & $3.76 \mathrm{e}-05$ & -3.804 & $0.000192 * * *$ \\
\hline $\mathrm{DF}$ & \multicolumn{4}{|c|}{191} \\
\hline Residual standard error & \multicolumn{4}{|c|}{0.008945} \\
\hline Multiple R-squared & \multicolumn{4}{|c|}{0.09516} \\
\hline Adjusted R-squared & \multicolumn{4}{|c|}{0.08095} \\
\hline
\end{tabular}

Source: Own results.

The model presented in (1) is designed to report the estimated coefficients to describe the relation between the immigration surplus and the independent variables. According to the estimations of the model that is shown in Table 1, the integration of immigrants through the SLR and the ALS both have a positive impact in the Immigration Surplus (IS) in the selected countries in the sample. In the same time, the integration of immigrants expressed through the AN variable has a negative impact in the Immigration Surplus during the same period in question. 


\section{Conclusions and policy implications}

Czech Republic represents an immigration country with all its characteristic features, yet the nature of the incoming migration is somewhat different from the other EU Member States, especially those constituting the EU15 countries. The majority of migrants from such countries and Syria or Afghanistan use the Czech Republic as a "bridge to the West" (mainly Germany and France), while those residing in the country are people of Slavic origin from Russian Federation, Belarus, and Ukraine. The majority of these international protection applicants and beneficiaries quickly find their way into the Czech labour market and successfully integrate into the society with $2 / 3$ of them operating as sole traders.

An interesting example of integration of immigrants in the Czech Republic is the case of the small vendors of Vietnamese origin. Although often lacking the good knowledge of Czech and having troubles to embrace the cultural norms of the mainstream society, Vietnamese migrants managed to root deeply into the Czech society and small business schemes making it impossible to imagine late-night shopping without visiting the Vietnamese store.

Economically speaking, it might be more rationale to allow the refugees and asylum seekers to become self-sufficient in economic sense. Micro-credits, stimulation of opening own business ventures and supporting pro-active approach towards economic and social integration might yield better results. The total monthly cost of meal and accommodation in Czech asylum facilities was CZK 8160 per person (around EUR 302) per month. In the same time, the subsistence minimum for the Czech residents CZK 3410 (around EUR 126) per person per month (the minimum does not include the housing costs). With regard to the above, it might be interesting to investigate what are the economic costs and benefits of international protection and labour market inclusion in the other EU countries which might become a topic of further research on that matter.

With regard to the MIPEX index-measured integration methodology, the Czech Republic remains "halfway favourable" for international protection applicants and beneficiaries (a terminology set up by the MIPEX index methodology which attributed the Czech Republic an overall score of 45 giving it between 41 and 59 points). Overall, the labour market inclusion of refuges and asylum seekers remains far from ideal and might requires some fundamental changes.

\section{References}

Ambrosetti, E., Cela, E., Strielkowski, W., Abrhám, J. (2014), Ukrainian Migrants in the European Union: a Comparative Study of the Czech Republic and Italy, Sociologija $i$ prostor/Sociology \& Space, 52(2), pp. 141-166.

Androniceanu, A. (2015), Good democratic governance based on a new model, Administratie si Management Public, (24), pp. 56-63.

Bilan, Y., Strielkowski, W. (2016), Migration in post-transition economies: immigration surplus in Visegrad group countries, International Journal of Trade and Global Markets, 9(2), pp. 182-196, DOI: http://dx.doi.org/10.1504/IJTGM.2016.076310.

Bilan, Y. (2014a), Labour migration of Ukraine's population: Scientific and public discourse, Transformations in Business and Economics, 13 (1), pp. 196-208.

Bilan, Y. (2014b), Migration aspirations on the outskirts of Europe: Social and economic dimensions, Transformations in Business and Economics, 13 (2B), pp. 606-614.

CSO (2016), Statistical Compendium, Available at: www.czso.cz. 
Lodewyckx, I., Timmerman, C., Wets, J. (2010), From nation state to migration state, Economics \& Sociology, 3 (2), pp. 9-22, DOI: http://dx.doi.org/10.14254/2071789X.2010/3-2/2.

Miłaszewicz, D., Milczarek, A., Nagaj, R., Szkudlarek, P., Zakrzewska, M. (2015), Determinants of Polish international migration in the area of the European Union after 2004, Journal of International Studies, 8(3), pp. 62-78, DOI: 10.14254/2071$8330.2015 / 8-3 / 5$.

MIPEX (2016), Migration Integration Policy Index, Available at: www.mipex.eu.

Mishchuk, H., Grishnova, O. (2015), Empirical study of the comfort of living and working environment - Ukraine and Europe: comparative assessment, Journal of International Studies, 8(1), pp. 67-80, DOI: 10.14254/2071-8330.2015/8-1/6.

Niessen, J., Huddelston, T., Citron, L., Geddes, A., Jacobs, D. (2007), Migrant Integration Policy Index (MIPEX), Migration Policy Group and British Council.

Office for National Statistics (2011), 2011 Census: Key Statistics and Key Statistics for Local Authorities in the United Kingdom, Available at: http://www.ons.gov.uk/peoplepopulationandcommunity/populationandmigration/popula tionestimates/bulletins/keystatisticsandquickstatisticsforlocalauthoritiesintheunitedkingd om/2013-10-11.

Office for National Statistics (2014), Population by country of birth and nationality report, Available at:

http://www.ons.gov.uk/peoplepopulationandcommunity/populationandmigration/interna tionalmigration/articles/populationbycountryofbirthandnationalityreport/2015-09-27.

Parliament (2016), Migration Statistics, House of Commons Library, Briefing Paper No. SN06077, Available at: http://www.parliament.uk/commons-library.

Stojanov, R., Strielkowski, W., Drbohlav, D. (2011), Labour migration and remittances: current trends in times of economic recession, Geografie, 116(4), pp. 375-400.

Strielkowski, W. (2012), Roma migrations: Economics of ethnicities and social groups in Central and Eastern Europe, Charles University in Prague.

Strielkowski, W., Ćábelková, I. (2015), Religion, Culture, and Tax Evasion: Evidence from the Czech Republic, Religions, 6(2), pp. 657-669, DOI: http://dx.doi.org/10.3390/rel6020657.

Strielkowski, W., Sanderson, M. (2013), Structural channels for Ukrainian labour migration in the Czech Republic, Trames, 17(3), pp. 313-324, DOI: http://dx.doi.org/10.3176/tr.2013.3.06.

Strielkowski, W., Weyskrabova, B. (2014), Ukrainian Labour Migration and Remittances in the Czech Republic, Tijdschrift voor economische en sociale geografie, 105, (1), pp. 3045, DOI: http://dx.doi.org/10.1111/tesg.12052.

Vasilopoulou, S. (2016), UK Euroscepticism and the Brexit Referendum, The Political Quarterly, 87(2), pp. 219-227, DOI: http://dx.doi.org/10.1111/1467-923X.12258. 